\title{
Sistem Pakar Diagnosa Penyakit Kulit Akibat Virus Menggunakan Teorema Bayes
}

\author{
Putri Taqwa Prasetyaningrum ${ }^{(1)}$, Nuri Budi Hangesti(2) \\ 1 Program Studi Sistem Infromasi, FakultasTeknologi Informasi, Universitas Mercu Buana \\ Yogyakarta JI. Wates KM. 10 Yogyakarta 55735, Indonesia \\ Email : putri@mercubuana-yogyakarta.ac.id(1)
}

\begin{abstract}
Skin is one of the most important organs in humans, because through the skin we can feel the feel and the surface of an object. If the skin is attacked, the disease may cause many consequences, such as from mild itching or to severe, the skin can not feel anything. Based on existing problems in the community created an application that can help people to recognize skin diseases suffered, so the level of awareness will keep the cleanliness higher, namely the application of expert system of viral skin disease using bayes theorem. In this research will be designed a system using method bayes theorem this expert system will be able to produce a diagnosis of skin diseases and treatment that needs to be done. With this application of course can help people to recognize the illnesses that have been allegedly allegedly to refer to injured. Based on 20 data that have been tested against experts and systems, for patients affected by viral skin diseases were 17 patients and those not infected were 3 patients. As for the suitability of testing between the validation results of experts (doctors) and the system, obtained percentage of $85 \%$.
\end{abstract}

\section{Keywords: Skin diseases, Expert system, Teorema Bayes.}

\begin{abstract}
Abstrak
Kulit adalah salah satu organ terpenting pada manusia, karena melalui kulit kita dapat merasakan rasa dan permukaan sebuah benda. Apabila kulit terserang penyakit maka akan banyak akibat yang akan ditimbulkannya, mulai dari yang ringan yaitu terasa gatal atau sampai yang berat yakni kulit tidak dapat merasakan apapun. Berdasarkan permasalahan yang ada di dalam lingkungan masyarakat diciptakan suatu aplikasi yang dapat membantu masyarakat untuk dapat mengenali penyakit kulit yang diderita, sehingga tingkat kesadaran akan menjaga kebersihan makin tinggi, yakni aplikasi sistem pakar penyakit kulit akibat virus. Pada penelitian ini akan dirancang sebuah sistem menggunakan metode Teorema Bayes. Sistem pakar ini nantinya dapat menghasilkan diagnosa penyakit kulit serta pengobatan yang perlu dilakukan. Dengan adanya aplikasi ini tentunya bisa membantu masyarakat mengenali penyakit yang dideritanya sehingga tersadar untuk merujuknya ke dokter ahli. Berdasarkan 20 data yang telah diujikan terhadap pakar dan sistem, untuk pasien yang terkena penyakit kulit akibat virus adalah 17 pasien dan yang tidak terkena infeksi adalah 3 pasien. Sedangkan untuk kesesuaian pengujian antara hasil validasi pakar (dokter) dan sistem, diperoleh tingkat persentase keberhasilan sebesar $85 \%$.
\end{abstract}

Kata Kunci : Penyakit kulit, Sistem Pakar, Teorema Bayes.

\section{PENDAHULUAN}

Penyakit kulit merupakan masalah yang komplek. Banyak faktor yang mempengaruhi timbulnya penyakit ini, diantaranya adalah faktor kebersihan, daya tahan tubuh (imunitas), kebiasaan, atau perilaku sehari-hari (makan, pergaulan, atau pola hubungan) seksual, faktor fisik, bahan kimia, mikrobiologi, serta faktor lingkungan (Rahariyani, 2006).

Kurangnya pengetahuan masyarakat mengenai penyakit kulit akibat infeksi virus dan pengobatan terhadap penyakit kulit, menyebabkan masyarakat tidak mengetahui gejala penyakit kulit. Perihal tersebut sangat berbahaya jika dibiarkan dan tidak segera dilakukan perawatan serta pengobatan yang tepat.

Pentingnya pendeteksian penyakit kulit sejak dini sangat diperlukan, sedangkan proses yang ada saat ini mengharuskan seseorang pergi ke tenaga medis yang ada. Hal tersebut sangat 
kontras dengan kondisi ekonomi seseorang yang berbeda-beda. Dimana seseorang harus mengeluarkan biaya untuk melakukan pendeteksian sejak dini terhadap penyakit kulit. Selain itu, kurangnya tenaga ahli khusus dibidang penyakit kulit juga menjadi salah satu factor keterlambatan penanganan penyakit kulit. Maka dari itu peneliti melakukan penelitian dengan judul sistem pakar diagnosa penyakit kulit akibat virus menggunakan metode Teorema Bayes. Diharapkan dari penelitian ini dapat membantu masyarakat untuk dapat mendeteksi dini terhadap penyakit kulit dan sebagai bahan pertimbangan tenaga medis dalam pendeteksian penyakit kulit.

\section{TINJAUAN PUSTAKA}

Penelitian dengan judul " Sistem Pakar Untuk Mengidentifikasi Penyakit Udang Galah Dengan Metode Teorema Bayes”, (Wahyudi \& Fadlil, 2013).

Penelitian dengan judul "Membangun Sistem Pakar Menggunakan Teorema Bayes Untuk Mendiagnosa Panyakit Paru-Paru", (Anggara , Pramayu, \& Wicaksana, 2016).

Penelitian dengan judul "Aplikasi Pakar Untuk Diagnosa Penyakit Kulit Menggunakan Metode Forward Chaining di Al Arif Skin Care Kabupaten Ciamis", (Nuraeni, Agustin, \& Yusup, 2016).

Penelitian dengan judul "Sistem Pakar Untuk Mendignosa Kulit Dengan Logika Fuzzy Decision Making", (Chandra \& Kosdiana, 2013).

Penelitian dengan judul "Sistem Pakar Menggunakan Teorema Bayes untuk Mendiagnosa Penyakit Kehamilan”, (Nugroho \& Wardoyo, 2013).

Penelitian ini fokus pada sistem pakar untuk diagnosa penyakit kulit akibat virus menggunakan Teorema Bayes. Penerapan metode Teorema Bayes dapat dilakukan dengan menentukan terlebih dahulu nilai probabilitas gejala terhadap masing-masing penyakit. Dalam penelitian ini, membahas tentang aplikasi sistem pakar untuk mendiagnosa penyakit kulit akibat virus. Data yang digunakan untuk penelitian terdiri dari 43 gejala dan 4 jenis penyakit.

\section{METODE PENELITIAN}

\subsection{Bahan Penelitian}

Bahan yang digunakan pada sistem pakar diagnosa penyakit kulit akibat virus dengan metode Teorema Bayes adalah sebagai berikut:

1. Data pasien dan pemeriksaan diperoleh dari data sistem informasi yang ada di Rumah Sakit.

2. Hasil wawancara yang membahas mengenai gejala-gejala serta validasi data sistem pakar dengan dokter ahli spesialis kulit.

3. Jurnal yang membahas mengenasi penyakit kulit, sistem pakar, dan metode Teorema Bayes.

\subsection{Jalan Penelitian}

Adapun teknik pengumpulan data sebagai berikut:

a. Studi kepustakaan

Studi kepustakaan dimulai dengan mengumpulkan data-data pemeriksaan pasien dari sistem informasi dirumah sakit. Data pemeriksaan ini berisi informasi data pasien. Dari data rekam medis pasien ini didapat data pasien sehingga dapat melengkapi struktur komponen dalam diagnosa penyakit kulit akibat virus dengan menggunakan Teorema Bayes. Berdasarkan data-data tersebut studi kepustakaan dilanjutkan dengan mencari gelaja dari tiap-tiap penyakit yang sudah didapat dari buku dari data gejala-gejala tiap penyakit ini

didapatkan nilai probabilitas gejala terhadap masing-masing penyakit, dalam menentukan nilai probabilitas ini yang wajib dan harus adalah seorang pakar yaitu Dr. 
Dyah Ayu Mira Oktarina, SpKK. Setelah nilai probabilitas didapat dari pakar dilanjutkan dengan mencari penanganan dari setiap penyakit yang ada sehingga melengkapi struktur komponen dalam diagnosa penyakit kulit akibat virus dengan metode Teorema Bayes. Dalam tahap pengujian, perhitungan yang dilakukan dengan Teorema Bayes adalah dengan menentukan terlebih dahulu nilai probabilitas gejala terhadap masingmasing penyakit.

b. Wawancara

Wawancara dilakukan untuk mendapatkan data-data penyakit kulit akibat virus dan validasi data dengan penyakit kulit akibat virus dengan mewawancarai dan melakukan unjuk kerja sistem kepada Dr. Dyah Ayu Mira Oktarina, SpKK. yang merupakan dokter spesialis kulit yang berada di Yogyakarta.

Alur penelitian dapat dilihat pada Gambar 1 .

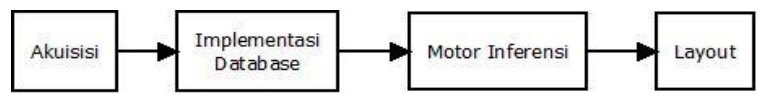

\section{Gambar 1. Alur Penelitian}

\subsection{Perancangan Database}

Perancangan database merupakan proses untuk menentukan isi data yang dibutukan untuk mendukung rancangan sistem. Model rancangan database yang dibangun adalah model relationship dimana seluruh tabel saling berhubungan satu dengan yang lain.

\subsection{Entity Relationship Diagram}

Entity Relationship Diagram (ERD) pada sistem pakar diagnosa penyakit kulit akibat virus, dapat dilihat pada Gambar 2.

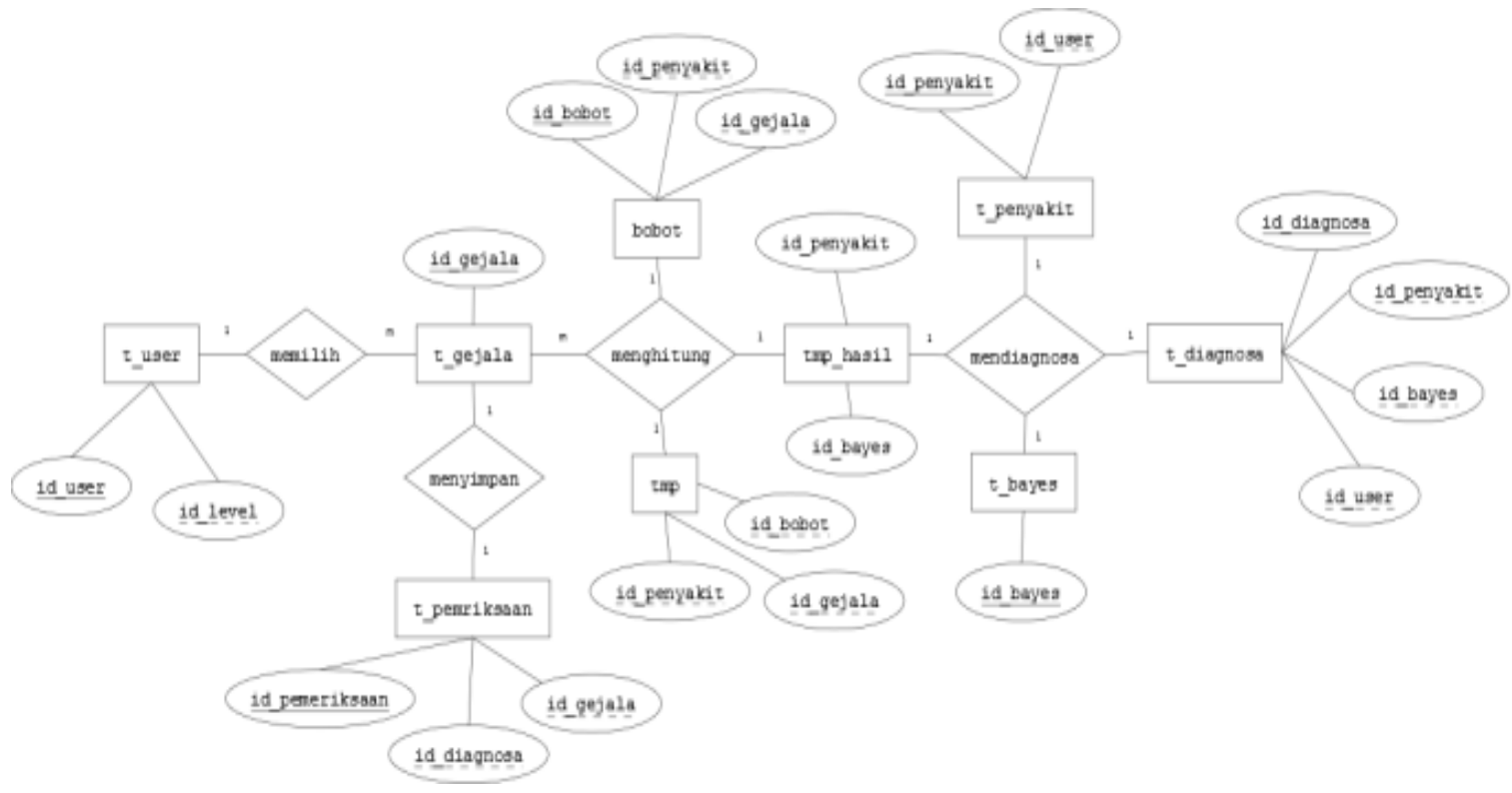

Gambar 2. Entity Relationship Diagram

\subsection{Basis Pengetahuan}

Basis pengetahuan mengandung pengetahuan untuk pemahaman, formulasi, dan penyelesaian masalah. Berikut ini adalah proses indexing yang dilakukan penulis untuk mengolah data yang akan digunakan dalam aplikasi ini. 
Tabel penyakit digunakan sebagai pola pencocokan informasi yang dimasukan oleh pemakai dan basis pengetahuan bisa dilihat pada Tabel 1 .

Tabel 1. Tabel Penyakit Kulit

\begin{tabular}{|l|l|}
\hline Kode Penyakit & Nama Penyakit \\
\hline P01 & Herpes Sinpleks \\
\hline P02 & Herpes Zoster \\
\hline P03 & Variola \\
\hline P04 & Varisela \\
\hline
\end{tabular}

Tabel gejala digunakan sebagai pola pencocokan informasi yang dimasukan oleh pemakai dan basis pengetahuan bisa dilihat pada Tabel 2 .

Tabel 2. Tabel Gejala Penyakit Kulit

\begin{tabular}{|l|l|}
\hline Kode & \multicolumn{1}{|c|}{ Gejala } \\
\hline G01 & Demam \\
\hline G02 & Sakit Kepala \\
\hline G03 & Malaise atau lesu \\
\hline G04 & Timbul vesikel atau bibtil-bintil berair yang menggrombol \\
\hline G05 & Rasa Gatal \\
\hline G06 & Rasa panas atau terbakar \\
\hline G07 & Ruam atau kemerahan pada daerah kulit \\
\hline G08 & Edema kulit \\
\hline G09 & Nyeri pada dermatom yang terserang \\
\hline G10 & Timbul papula atau bintik-bintik menonjol \\
\hline G11 & Timbul makula atau bintik-bintik datar \\
\hline G12 & Sensitif terhadap cahaya \\
\hline G13 & Kesemutan \\
\hline G14 & Fatigue atau kelelahan \\
\hline G15 & Muntah- muntah atau Anorexia \\
\hline G16 & Sakit punggung \\
\hline G17 & Sakit tenggorokan \\
\hline G18 & Vesikula di badan \\
\hline G19 & Lesi di wajah/eksremitas \\
\hline G20 & Erupsi \\
\hline G21 & Ruam / kemerahan dikulit atau Polimorf \\
\hline G22 & Nyeri tulang atau sendi \\
\hline G23 & Gelisah \\
\hline G24 & Ruam / kemerahan dikulit atau Monomorf \\
\hline G25 & Vesikula tipis (seperti tetesan embun/ tear drops) \\
\hline G26 & Timbul makula eritematosa kemudian menjadi papula \\
\hline G27 & Erupsi terjadi bergelombang \\
\hline G28 & Vesikula tebal dan tegang \\
\hline G29 & Myalgia/nyeri pada bagian otot \\
\hline G30 & Kemerahan \\
\hline & \\
\hline
\end{tabular}

Tabel bobot digunakan sebagai pola pencocokan informasi yang dimasukan oleh pemakai dan basis pengetahuan bisa dilihat pada Tabel 3 .

Tabel 3. Bobot

\begin{tabular}{|l|l|l|}
\hline $\begin{array}{l}\text { Kode } \\
\text { Gejala }\end{array}$ & $\begin{array}{l}\text { Kode } \\
\text { Penyakit }\end{array}$ & Bobot \\
\hline G01 & P01 & 0.7 \\
\cline { 2 - 3 } & P02 & 0.5 \\
\hline
\end{tabular}




\begin{tabular}{|c|c|c|}
\hline $\begin{array}{l}\text { Kode } \\
\text { Gejala }\end{array}$ & $\begin{array}{l}\text { Kode } \\
\text { Penyakit }\end{array}$ & Bobot \\
\hline & P03 & 0.5 \\
\hline & P04 & 0.5 \\
\hline \multirow[t]{4}{*}{ G02 } & P01 & 0.5 \\
\hline & P02 & 0.9 \\
\hline & P03 & 0.7 \\
\hline & P04 & 0.7 \\
\hline \multirow[t]{4}{*}{ G03 } & P01 & 0.5 \\
\hline & P02 & 0.6 \\
\hline & P03 & 0.7 \\
\hline & P04 & 0.7 \\
\hline \multirow[t]{2}{*}{ G04 } & P01 & 1 \\
\hline & P02 & 1 \\
\hline \multirow[t]{2}{*}{ G05 } & P01 & 0.2 \\
\hline & P02 & 0.5 \\
\hline \multirow[t]{2}{*}{ G06 } & P01 & 1 \\
\hline & P02 & 1 \\
\hline G07 & P01 & 0.5 \\
\hline G08 & P01 & 0.5 \\
\hline G09 & P02 & 1 \\
\hline G10 & P02 & 1 \\
\hline G11 & P02 & 0.5 \\
\hline G12 & P02 & 0.5 \\
\hline G13 & P02 & 0.2 \\
\hline G14 & P02 & 0.5 \\
\hline \multirow[t]{2}{*}{ G15 } & P03 & 0.2 \\
\hline & P04 & 0.2 \\
\hline G16 & P04 & 0.2 \\
\hline G17 & P04 & 0.7 \\
\hline G18 & P03 & 0.5 \\
\hline G19 & P04 & 0.8 \\
\hline G20 & P03 & 0.9 \\
\hline G21 & P04 & 0.9 \\
\hline G22 & P03 & 0.5 \\
\hline G23 & P03 & 0.1 \\
\hline G24 & P03 & 1 \\
\hline G25 & P04 & 1 \\
\hline G26 & P03 & 1 \\
\hline G27 & P04 & 0.7 \\
\hline G28 & P03 & 0.5 \\
\hline G29 & P01 & 0.2 \\
\hline G30 & P02 & 0.5 \\
\hline
\end{tabular}

Tabel aturan bayes dapat dilihat pada Tabel 4 .

Tabel 4. Tabel Aturan Bayes

\begin{tabular}{|r|l|l|}
\hline No & $\begin{array}{l}\text { Nilai } \\
\text { Bayes }\end{array}$ & Teorema Bayes \\
\hline 1. & $00-0.2$ & Tidak Ada \\
\hline 2. & $0.3-0.4$ & Mungkin \\
\hline 3. & $0.5-0.6$ & Kemungkinan \\
\hline 4. & $0.7-0.8$ & Hampir Pasti \\
\hline 5. & $0.9-1$ & Pasti \\
\hline
\end{tabular}


Tabel 5. Data Rekamedik Pasien

\begin{tabular}{|l|l|l|}
\hline No & $\begin{array}{l}\text { No } \\
\text { rekam } \\
\text { medis }\end{array}$ & \\
\hline 1 & 136288 & G04,G05,G06,G29 \\
\hline 2 & 135622 & G01,G16,G17,G25,G21 \\
\hline 3 & 125400 & G01,G03,G26 \\
\hline 4 & 125350 & G01,G04,G29,G30 \\
\hline 5 & 026519 & G09,G05,G06,G04,G30 \\
\hline 6 & 054639 & G01,G09,G05,G10,G04,G13 \\
\hline 7 & 123105 & G01,G03,G25 \\
\hline 8 & 105382 & G01,G03,G26,G22,G24 \\
\hline 9 & 109859 & G01,G02,G05,G10 \\
\hline 10 & 136354 & G25,G21,G27 \\
\hline 11 & 049207 & G01,G03,G25,G21 \\
\hline 12 & 114239 & G01,G04,G05,G06,G30 \\
\hline 13 & 111492 & G01,G03,G25 \\
\hline 14 & 080354 & G01,G25,G21 \\
\hline 15 & 080806 & $\begin{array}{l}\text { G01,G02,G09,G05,G06,G04, } \\
\text { G30 }\end{array}$ \\
\hline 16 & 108263 & G01,G04,G05,G06 \\
\hline 17 & 125570 & G01,G18,G15,G26,G24 \\
\hline 18 & 099980 & G05,G04,G13 \\
\hline 19 & 048874 & G01,G03,G24,G26 \\
\hline 20 & 118888 & G01,G04,G05, G08,G30 \\
\hline & & \\
\hline
\end{tabular}

3.6. Motor Inferensi

Motor inferensi berupa flowchart menggunakan metode Teorema Bayes dapat dilihat pada Gambar 4. 


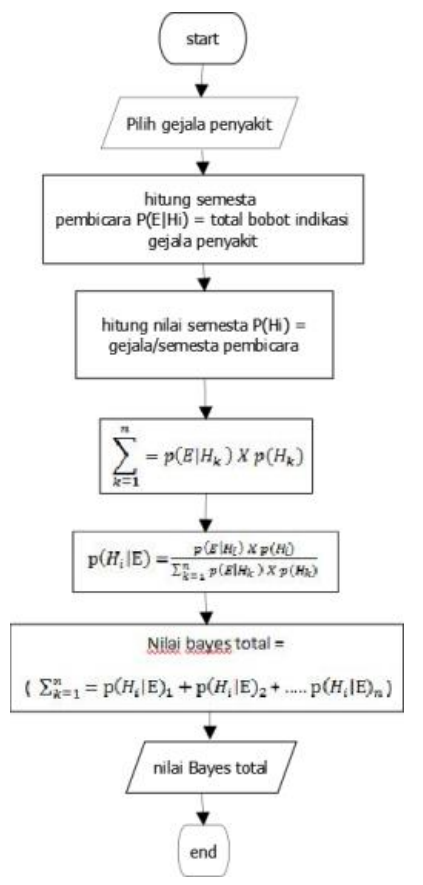

Gambar 4. Flowchart Motor Inferensi

\section{HASIL DAN PEMBAHASAN}

\subsection{Hasil Penelitian}

Hasil pengujian yang dilakukan pada sistem pakar diagnosa penyakit kulit akibat virus pada pasien menunjukan unjuk kerja sistem yang sesuai dengan keterangan yang didapat dari pakar.

\subsection{Proses Inferensi}

Pada proses inferensi adalah menghitung data sampel pengujian pada Tabel 4.1. Langkah perhitungan adalah sebagai berikut :

1. Mencari nilai semesta

Mencari nilai semesta dengan menjumlahkan seperti pada Persamaan 4.1.

$$
\begin{aligned}
& \sum_{G 09}^{P 01} \mathrm{~K}=1=\mathrm{G} 1+\mathrm{G} 2+\mathrm{G} 3+_{x, x} \mathrm{n} \\
= & 0.7+0.5+0.5+1+0.2+1+0.5+0.5+0.2 \\
= & 5.1
\end{aligned}
$$

2. Menghitung nilai semesta $\mathrm{P}(\mathrm{Hi})$

Setelah hasil penjumlahan nilai semesta diketahui, maka didapatkan rumus untuk menghitung nilai semesta $\mathrm{P}(\mathrm{Hi})$, seperti pada Persamaan 4.2.

$$
P(H 1,2, \ldots n)=\frac{H 1, H 2, \ldots . n}{\sum_{k=1}^{p 01}}
$$

$$
\begin{aligned}
& \mathrm{P}(\mathrm{H} 1)=0.7 / 5.1=0.1372 \\
& \mathrm{P}(\mathrm{H} 2)=0.5 / 5.1=0.0980 \\
& \mathrm{P}(\mathrm{H} 3)=0.5 / 5.1=0.0980 \\
& \mathrm{P}(\mathrm{H} 4)=1 / 5.1=0.1960 \\
& \mathrm{P}(\mathrm{H} 5)=0.2 / 5.1=0.0392
\end{aligned}
$$




$$
\begin{aligned}
& \mathrm{P}(\mathrm{H} 6)=1 / 5.1=0.1960 \\
& \mathrm{P}(\mathrm{H} 7)=0.5 / 5.1=0.0980 \\
& \mathrm{P}(\mathrm{H} 8)=0.5 / 5.1=0.0980 \\
& \mathrm{P}(\mathrm{H} 9)=0.2 / 5.1=0.0392
\end{aligned}
$$

3. Menghitung probabilitas $\mathrm{H}$

Setelah seluruh nilai $\mathrm{P}(\mathrm{Hi})$ diketahui, dilanjutkan menghitung probabilitas $\mathrm{H}$ tanpa memandang evidence apapun, seperti pada Persamaan 4.3. Menghitung probabilitas $\mathrm{H}$ tanpa

$$
\sum_{G 09}^{P 01}=P(H i) \times P(E \mid H i-n)
$$

$\mathrm{P}(\mathrm{H} 3) \times \mathrm{P}(\mathrm{E} \mid \mathrm{H} 3)=0.1372 \times 0.7=0.0960$

$\mathrm{P}(\mathrm{H} 3) \times \mathrm{P}(\mathrm{E} \mid \mathrm{H} 3)=0.0980 \times 0.5=0.0490$

$\mathrm{P}(\mathrm{H} 3) \times \mathrm{P}(\mathrm{E} \mid \mathrm{H} 3)=0.0980 \times 0.5=0.0490$

$\mathrm{P}(\mathrm{H} 3) \times \mathrm{P}(\mathrm{E} \mid \mathrm{H} 3)=0.1960 \times 1=0.1960$

$\mathrm{P}(\mathrm{H} 3) \times \mathrm{P}(\mathrm{E} \mid \mathrm{H} 3)=0.0392 \times 0.2=0.0078$

$\mathrm{P}(\mathrm{H} 3) \times \mathrm{P}(\mathrm{E} \mid \mathrm{H} 3)=0.1960 \times 1=0.1960$

$\mathrm{P}(\mathrm{H} 3) \times \mathrm{P}(\mathrm{E} \mid \mathrm{H} 3)=0.0980 \times 0.5=0.0490$

$\mathrm{P}(\mathrm{H} 3) \times \mathrm{P}(\mathrm{E} \mid \mathrm{H} 3)=0.0980 \times 0.5=0.04901$

$\mathrm{P}(\mathrm{H} 3) \times \mathrm{P}(\mathrm{E} \mid \mathrm{H} 3)=0.0392 \times 0.2=0.0078$

Total Hipotesa $(\mathrm{H})=0.7$

4. Mencari nilai $\mathrm{P}(\mathrm{Hi} \mid \mathrm{E})$

Untuk menghitung nilai $\mathrm{P}(\mathrm{Hi} \mid \mathrm{E})$ mengacu pada tabel sampel data pengujian yaitu di tabel 4.2 dan seperti pada Persamaan 4.4.

$$
\mathrm{P}(\mathrm{H} \mid \mathrm{E})=\frac{p(E \mid H) x p(H)}{p(E)}
$$

$$
\begin{aligned}
& \mathrm{P}(\mathrm{H} 1 \mid \mathrm{E})=0.7 \times 0.1372 / 0.7=0.1372 \\
& \mathrm{P}(\mathrm{H} 2 \mid \mathrm{E})=0 \times 0 / 0.7=0 \\
& \mathrm{P}(\mathrm{H} 3 \mid \mathrm{E})=0 \times 0 / 0.7=0 \\
& \mathrm{P}(\mathrm{H} 4 \mid \mathrm{E})=1 \times 0.1960 / 0.7=0.2801 \\
& \mathrm{P}(\mathrm{H} 5 \mid \mathrm{E})=0.2 \times 0.0392 / 0.7=0.0112 \\
& \mathrm{P}(\mathrm{H} 6 \mid \mathrm{E})=0 \times 0 / 0.7=0 \\
& \mathrm{P}(\mathrm{H} 7 \mid \mathrm{E})=0 \times 0 / 0.7=0 \\
& \mathrm{P}(\mathrm{H} 8 \mid \mathrm{E})=0.5 \times 0.0980 / 0.7=0.0700 \\
& \mathrm{P}(\mathrm{H} 9 \mid \mathrm{E})=0.5 \times 0.0980 / 0.7=0.07002
\end{aligned}
$$

5. Menghitung total nilai bayes

Setelah seluruh nilai $\mathrm{P}(\mathrm{Hi} \mid \mathrm{E})$ diketahui, jumlahkan seluruh nilai bayes seperti pada Persamaan 4.5.

$$
\sum_{n=4}^{P 01} \text { Bayes }=\text { Bayes } 1+\text { Bayes } 2+\text { Bayes } 3+\ldots x, x, n
$$

$$
=0.1372+0+0+0.2801+0.0112+0+0+0.0700+0.0700
$$

$$
=0.5686
$$

Pada perhitungan bayes diperoleh nilai 0.5686 , jika dicocokan dengan tabel aturan bayes, maka hasilnya $0.5-0.6$ yang artinya "Kemungkinan Besar". 


\section{KESIMPULAN}

Dari penelitian yang dilakukan, kesimpulan yang dapat diperoleh adalah sebagai berikut :

1. Berdasarkan 20 data yang telah diujikan terhadap pakar dan sistem, untuk pasien yang terkena penyakit kulit akibat virus adalah 17 pasien dan yang tidak terkena infeksi adalah 3 pasien. Sedangkan untuk kesesuaian pengujian antara hasil validasi pakar (dokter) dan sistem, diperoleh tingkat persentase keberhasilan sebesar $85 \%$.

2. Sistem dirancang dengan mengimplementasikan metode teorema bayes supaya dapat digunakan untuk membantu dalam mendiagnosa penyakit kulit akibat infeksi virus.

\section{DAFTAR PUSTAKA}

Anggara, G., Pramayu, G., \& Wicaksana, A. (2016). Membangun Sistem Pakar Menggunakan Teorema Bayes Untuk Mendiagnosa Penyakit Paru-Paru. Seminar Nasional Teknologi Informasi dan Multimedia, (pp. 3.5-79-3.5-84). Yogyakarta.

Chandra, Y. I., \& Kosdiana. (2013). Aplikasi Tablet Pc Untuk Mendeteksi Penyakit Kulit Menggunakan Metode Fuzzy Decision Making (FDM). Jurnal Cybermatika.

Graham-Brown, R., \& Burns, T. (2005). Lecture Notes Dermatologi (8 ed.). Jakarta: Erlangga. Harahap, M. (2000). IImu Penyakit Kulit. Jakarta: Hipokrates.

Nugroho, A. K., \& Wardoyo, R. (2013). Sistem Pakar Menggunakan Teorema Bayes Untuk Mendiagnosa Penyakit Kehamilan. Berkala MIPA, 247-254.

Nuraeni, F., Agustin, Y. H., \& Yusup, E. N. (2016). Aplikasi Pakar Untuk Diagnosa Penyakit Kulit Menggunakan Metode Forward Chaining di Al Arif Skin Care Kabupaten Ciamis. Seminar Nasional Teknologi Informasi dan Multimedia, (pp. 3.4-(55-60)). Yogyakarta.

Rahayani, L. D. (2006). Asuhan Keperawatan Klien Ganguan Sistem Integumen. Jakarta: EGC. Sutojo, T., mulyanto, E., \& suhartono, V. (2011). kecerdasan buatan. yogyakarta: ANDI.

Wahyudi, M. J., \& Fadlil, A. (2013). Sistem Pakar Untuk Mengidentifikasi Penyakit Udang Galah Dengan Metode Teorema Bayes. Jurnal Sarjana Teknik Informatika, 12-20. 